\title{
How neoliberal globalization processes are transforming Kyiv's nodal areas
}

The abandonment of Soviet urban planning approaches, the liberalization of appertaining legislation, confusion under the pressure of business priorities, and the lack of a national urban strategy make Ukrainian cities vulnerable to ongoing change. This article analyses the current urban functional and spatial transformations that result from the influences of neoliberal globalization. It considers Kyiv's nodal areas as the focus of major structural changes. The methodology addresses these processes, including their characteristics and salient features. Because of their social and historical significance, some nodal areas are acquiring more cultural and symbolic value, but at the same time the impact of certain ill-conceived replacements of the original functions can be observed in practice. The study identified forty-four nodal areas and classified six types of transformations according to their social and cultural value. In most nodal areas, the cultural, aesthetic, representative, and communication functions are being replaced by commercial, service, and transport land uses. Selected case studies demonstrate the importance of continued public involvement in reorganizing Kyiv's urban space.

Keywords: urban structure, city nodal areas, neoliberal globalization, functional and spatial transformations, Kyiv 


\section{Introduction}

The processes of world economic globalization and their influences on cities have been discussed by researchers since Geddes (1915). It is now clear that cities are the key generators and repeaters of global changes and the "backbone" of the global economy (Friedmann \& Wolff, 1982; Friedmann, 1986; Hall, 1993; Sluka, 2007). At the same time, a city's environment becomes the first recipient of global changes, including emerging opportunities and challenges (Sassen, 2016). Market-driven urban development considers settlements to be mere economic assets that can be stripped of historical, social, and symbolic meanings, and turned into easily marketable commodities (Balibrea, 2001; Short, 2004; Križnik, 2011, 2018). These neoliberalization processes have been reshaping the landscapes of urban development for more than three decades; their combined forms and consequences continue to evolve through an eclectic blend of failure and crisis, regulatory experimentation, and policy transfer across places, territories, and scales (Peck et al., 2013).

A special type of "cities in globalization" (Taylor, 2006) is emerging in post-communist cities. These cities undergo various transformational processes caused by both globalization and the emergence of a market economy (Mezentsev, 2015). Urban landscapes formed under communism are being adapted and remodelled to new conditions shaped by the political, economic, and cultural transition to capitalism (Sykora, 2009). Looking at the morphology, land use, and social segregation in these cities, some typical capitalist city areas can be documented, while alongside there remain sections of urban landscapes that resemble frozen mirrors of communism (Sýkora \& Bouzarovski, 2012).

For post-communist countries, including Ukraine, global impulses are superimposed on a number of internal features, many viewed as relics of the previous era. This complex patchwork strengthens the image of urban landscape transformation and also poses problems of preserving its attractiveness while at the same time seeking increasing functionality and innovativeness. In a socio-political context, it refers to an incomplete transition from rigid regulation and directive planning to one of a competitive business environment (Maruniak, 2007). Kyiv, which sees its role as the main recipient of global impacts in Ukraine as both the nation's capital and largest metropolis, is of particular interest in addressing these transformations. To investigate Kyiv's current transformations, we selected a specific urban structural element; namely, the city's nodal area. This site includes places that play the leading role in the urban planning structure due to the concentration of processes and functions essential to the city's daily life. This urban space has a direct impact on the city's emerging spatial identity. The attractiveness of nodal areas for various activities makes them both dynamically variable and vulnerable, often resulting in a loss of their authenticity and their social and cultural value. Below we first address the theoretical focus and discuss methodological approaches used in defining a city's nodal areas and identifying their transformations under conditions of neoliberal urban development. Second, at a more practical level, we identify Kyiv's nodal areas, taking into account their transformations; we also create a spatial model depicting those functional and spatial formations and patterns. Third, we illustrate those changes using case studies to inform the city planners how neoliberal transformations affect urban space and how public participation aids in making decisions regarding people's livelihood and urban development.

\section{Theoretical background 2.1 Global neoliberal transformations and the city}

Space is considered a social product in the early works of critical geographers and sociologists, including Lefebvre (1968, 1970, 1974), Jacobs (1961, 1970), Foucault (1967), Harvey (1973), and Castells (1977). Attention is focused on the fact that under current conditions related to urban planning priority is often directed to economic interests, with the needs of the local population not taken into account. In his research on postmodern urbanization, Soja (2008) seeks to emphasize that urban space creates innovation, creativity, and economic growth, but at the same time establishes additional hierarchy, inequality, social polarization, and injustice.

Cities are involved in the processes of world competition as a result of globalization influences (Salvati \& Zitti, 2017). Marcuse and Van Kempen (2000) initiated the discussion about the social and spatial consequences of such involvement, which changes the economic and cultural functions and tasks of the city and simultaneously transforms the concept of urban planning. Urban planning is primarily aimed at creating a favourable business climate and restructuring the urban space and its manifestations in terms of architecture, image, and perception, all designed to meet certain standards that allow the city to attract international capital (Taylor et al. 2007, 2010). In the globalization process, despite performing a variety of functions from religious to military, cities have been subordinated to one major function; namely, to promote the centralization of capital (Trubina, 2011). In this regard, in recent decades the globalization process has become enormously influential in explaining changes within cities. 
Following Harvey $(1973,1989)$, a number of critical geographers have focused on the study of new management structures in urban planning, as well as the impact of the real estate market on neoliberal urban development (Jessop, 1997; Peck \& Tickell, 2002; Brenner \& Theodore, 2002, 2003; Peck et al., 2013; Brenner \& Schmid, 2014; Peck et al. 2017). The findings by Swyngedouw, Moulaert, and Rodriguez (Moulaert, 2000; Moulaert et al., 2001a, 2001b; Swyngedouw, 2002) are important in focusing attention on the issues addressed here. In analysing recent developments in several European cities, they modelled a new theoretical framework regarding contemporary neoliberal urbanization processes. They identified the interactions of three phenomena as being responsible for changing the order of urban development: 1) a neoliberal economic policy of the state that is related to market liberalization, deregulation, and privatization; 2) a new urban policy in which coalitions between the public and private sectors, as well as political and economic trends, enter the sphere of urban planning and development; and 3) urban development projects that discover new economic potentials and generate money. At the same time, it is recognized that a large part of the population impacted by such projects is simultaneously excluded from the planning and management process, which leads to socio-spatial polarization. The main aim of such urban planning initiatives is to generate rent from real estate developments and decouple urban planning from social urban development (Al-Hamarneh, 2011). Many cities in post-Soviet countries began to apply this planning approach in their urban management practices immediately following the Soviet Union's collapse.

Neoliberalism is commonly acknowledged as the dominant ideology driving post-communism (Pickles \& Smith, 1998; Birch \& Mykhnenko, 2010; Stenning et al., 2010). Golubchikov et al. conceptualize these post-communist urban economic geographies through the notion of hybrid spatialities that emerge from the mutual embeddedness of neoliberalism and communist legacies. They argue that the communist legacy has been alienated from its history and has become an infrastructure of neoliberalization (Golubchikov et al., 2013). The systematization of these transformation processes in post-communist cities in the context of globalization is considered in many works, including publications by Russian and Slovak geographers that discuss the power of influence of these processes in various parts of the city, including core-periphery relations (Sluka, 2009) and distinctive morphological, functional, and socio-demographic features (Matlovic et al., 2009).

In recent years, changes in urban space under the influence of neoliberal globalization processes have received attention in Ukraine. The impacts of globalization on various aspects of urban development are discussed by Maruniak (2007,
2013), Mezentsev et al. (2012, 2015), and Mezentseva (2017). Maruniak (2013) observes the challenges faced by post-Soviet cities in Ukraine. These include a marked social hierarchy, information and communication oversaturation, an increasing presence of global actors, loss of urban landscape originality, strengthening multiculturalism of the urban environment, an accelerated pace of change, and risks to sustainable development. Among the processes that most affect changes in urban space are aggressive privatization, commercialization, functional fragmentation, tertiarization, social polarization, and spatial segregation (Mezentsev \& Mezentseva, 2012). The theoretical basis of research on global neoliberal urbanization and the context and transformations occurring in Kyiv are addressed in Al-Hamarneh et al. (2013) and Dronova et al. $(2013,2018)$. An analysis of the problems and prospects facing the development of Ukraine's capital city was made by Nudelman (2015), and a review of the post-industrial transformation of major Ukrainian cities was conducted by Pidgrushnyi (2015). These authors focus on current conditions related to ownership of land and properties in Kyiv and the replacement of traditional urban planning issues in the classic sense of structure and composition (Sosnova, 2011; Nudelman, 2013; Dronova \& Poleshko, 2017).

\subsection{Identifying city nodal areas}

Due to changes associated with globalization, the transformations of urban space are the most evident within a city's nodal areas. Over fifty years ago, Kevin Lynch defined nodes as the leading spatial element in the mental map of the city - strategic points that the observer can freely enter. They are the crossroads or places of concentration of some special properties and are reflected in people's imagination mostly as compact points. In reality, however, they can be spacious squares or extended linear spaces and even central districts. If one considers the territory at the highest hierarchical urban level (national or global), then the city can be considered a node (Lynch, 1960). Lynch's perspective conveys a humanistic direction in terms of perceptual categories. The visual perception provides new perspectives useful in exploring new strategies for urban design and providing ways residents can envision their wellbeing in urban space (Morello \& Ratti, 2009). Of Lynch's five key spatial elements of a city (paths, edges, districts, nodes, and landmarks), three of them - paths, nodes, and edges - were identified as significantly important in physical, perceptual, and psychological terms (Stevens, 2006). Norberg-Schulz (1971, 1980) likewise suggests that these three elements are not merely cognitive, but also behavioural. They are "existential": they organize human dwelling in the landscape at all scales and are the fundamental topological structure of space in relation to movement and visibility in that they define continuity, choice, and enclosure, respectively. 
Following Lynch's seminal work, many studies recognized that some city elements may be memorable or "imageable" not because of their visual stimulus, but because they possess some personal, historical, or cultural meaning (Appleyard, 1969; Golledge et al., 1978). For example, the geometric or visual appearance of a little house may be unremarkable in its surroundings, but it becomes memorable because a well-known person lived there; thus, the meaning or semantics make the house a landmark (Jiang, 2012). Stevens (2006) also developed a comprehensive, robust model of urban morphology from a phenomenological and behavioural perspective. He defined intersections (nodes) as places of heightened awareness and decision-making where people slow down or stop and make choices about what they will do next and where they are going. Thus, they define their itinerary, although not always on pragmatic grounds. Intersections provide a broadened field of vision, opening up new options for experience and directions for movement. At intersections people can be distracted from their original intentions. It is assumed that the functional and aesthetic environments of nodes play a significant role in creating a sense of place.

\section{Methods}

Below we summarize the results of research on Kyiv's nodal areas over the past several years within the context of their heritage, functioning, and deployment of various activities during the Soviet period and after Ukraine's independence. Particular attention was paid to changes in the functions and urban space under the influence of neoliberal and global impacts, in particular commercializationand tertiarization processes, the emergence of business and shopping centres, the offices of transnational corporations and international capital, and subsequent reshaping of public space. The methods include visual observations, specific methods of human geography (e.g., statistical, comparative-geographical, graphic, and cartographic methods), and historical methods. These combined methods contribute to the creation of a spatial model of Kyiv's nodal areas and an analysis and assessment of their transformations.

The research was conducted in several stages. Initially, field data were gathered with an emphasis on the location of the nodal areas; specifically, their architectural solutions, original functions, and transformations. At the second stage, research and statistical documents, maps, and photographs of the Soviet and post-Soviet period containing information on the planning system were gathered, as well as quantitative and functional parameters of individual areas of the city. The third stage involved examining various public documents, defining nodal territories, and setting the criteria for those selected for in-depth analysis. An analysis of their transformation processes was conducted with an emphasis on changing social and cultural functions. This stage also included the classification of the nodal areas, taking into account their transformations. At the same time, more detailed case studies of those areas with the highest social significance were carried out.

Following Lynch's definition of nodal areas, we consider them as places or strategic points (foci) of the city; that is, those that have free access, are mainly located at the crossroads of important transport routes, have a large concentration of urban functions, and are characterized by both centripetal and centrifugal flows. These route intersections are particularly important for city residents because the transition from one transport $/ \mathrm{com}$ munication mode to another is perceived as moving from one structural element to another. The concept of a nodal area is one close to describing a "transportation hub," which is treated as a point where different types of transport converge and there is a transfer of passengers and goods from one mode to another. In this context, the city's nodal areas could be city squares or the intersection of important transport routes of the city where some streets are crucial for the city to function. However, it is not only traffic connections that are important nodal areas; it is appropriate to start with the notion of "process nodes," which represent "the passing, progression, a logical and consequent change of events, conditions and stages of development. Geospatial processes are the processes of interaction between geographical objects located on a specific territory and developing in time" (Alaev, 1977: 159). Thus, city nodal areas play the leading role in the city's urban planning structure due to the concentration of processes essential to the life of the city and related city functions. These are places where the intersections of material and spiritual paths, transport and human flows, information and communication links, and concentrations of interests of representatives of different forms of ownership as well as places of origin and the resolution of conflicts occur. The emergence of these "intersections of processes" leads to a concentration of transport, cultural, economic, social, administrative, communication, and service functions.

Traditionally, the elements of a city's mental map, including its nodes, are communicated through interviewing residents. With advances in computer technology, the image of the city can be studied in a quantitative manner by using results of surveys. For example, the syntactic image of the city can be based on space syntax research (Dalton \& Bafna, 2003) or a digital image using 3D visual fields (Eugenio \& Ratti, 2009). Jiang (2012) discusses how the image of the city can be automatically computed from geospatial databases. This is possible because the city possesses a living structure that contains an intrinsic hierarchy of artefacts. Thus, both legibility and the imageability of city artefacts can be quantified through a process of ranking the individual city artefacts in terms of 


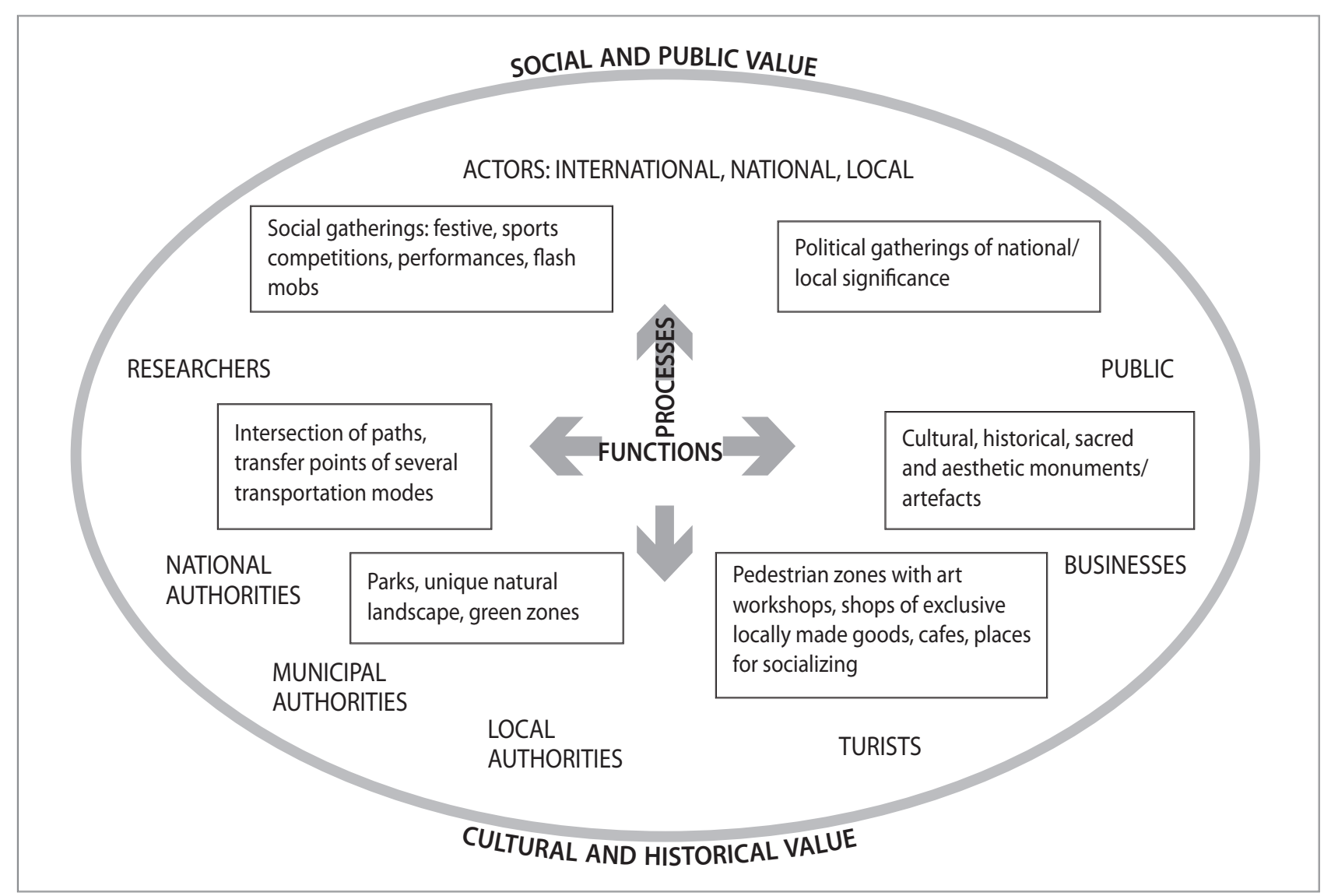

Figure 1: Logical scheme of a city nodal area (illustration: Olena Dronova).

semantic, topological, and geometric information. Although this approach has value, such a method is acceptable only for the material artefacts of the city. These combined processes and functions are better assessed using qualitative methods than a quantitative assessment.

From the perspective of human geography, taking into account all the historical, economic, and spatial aspects as well as social interests and movements in daily urban life and analysing the fundamental properties and features of cities themselves (see Lappo, 1997), we identified the defining characteristics of the city's nodal areas. They are pedestrian and transport accessibility; a high level of logistics; historical stratification; specialization; dynamism of functioning and, to a lesser extent, the dynamism of development; vulnerability to globalization impacts; the special attractiveness for various spheres of activity (private and public); dominant social significance; self-development; and the likelihood of conflicts.

In this context, Lynch (1960) distinguishes two types of nodes: those at major intersections and those characterized by a concentration of some activity. However, depending on the purpose of a scholarly or planning inquiry, such a distinction may not be especially informative (Dalton \& Bafna, 2003).
In order to expand the current understanding of the types of city nodal areas, it is important to consider their pervasive social and public value. We consider the following to be the distinguishing criteria:

- Places where transfer points intersect using several modes of transportation;

- Places where important political gatherings of national or local significance (both organized and spontaneous) frequently occur;

- Places of frequent major festive, sports, and social events, performances, and flash mobs;

- The presence of cultural, historical, sacred, and aesthetic monuments, artefacts, buildings, and structures;

- The presence of pedestrian zones with art workshops, shops with exclusive locally made goods, cafes, and places of communication, recreation, and relaxation; and

- Places where parks and unique natural landscape elements are blended into the urban design.

Some nodal areas emerge on the basis of historical meeting places or marketplaces, or as the centres of the city's planning districts. Separate nodal areas play the role of etherialization and are akin to spiritual centres of the city (Mumford, 1961). They are the historical centres of cities, those territories that 
are memorable due to the events that happened there, and squares that are distinct due to concentrations of sacral, cultural, and educational institutions, and architectural compositions of high aesthetic value. Obviously, the more distinctive the node, the more memorable it will be (Haken \& Portugali, 2003; Hospers, 2010). Theoretically, nodal areas should acquire additional cultural and symbolic value through their social and historical or architectural significance (Figure 1). In theory, cultural and symbolic value should be preserved and maintained through the joint efforts of the municipal authority and public community. The role of the public, NGOs, and local communities is difficult to overestimate. Using the example of certain nodal areas, it is possible to track how the public is effective in thwarting the process of their chaotic development and seeks to preserve the unique appearance and value of nodal areas.

There are many examples of residents in a city's nodal areas raising concerns about their immediate inherent architectural appearance and stability. This situation arises when looking at developments in post-communist Ukrainian cities. In places where the existing functions and processes are concentrated, the processes of permanent replacement of those functions, as well as the corresponding reorganization, are most notable and visible in public awareness. Under the influences of neoliberal and globalization processes, a city's nodal areas become the most attractive for various business activities, and, in cases of constant changes of actors and priorities, they represent some of the most dynamic thinking. Thus, from a broad perspective on urban territory, these areas are the most vulnerable to permanent globalization changes. In this light it is worth noting that their cultural and architectural symbolism bears the burden of responsibility for displaying both their uniqueness and territorial identity.

\section{Analysis of Kyiv's nodal areas and their major transformations}

Due to the transition from communism to a post-communist political regime and a market economy, the main nodal areas of Ukraine's capital city have experienced the most changes. Historically, most of the city's squares perform commercial and trade functions and serve as public spaces where residents can congregate and communicate. Today, the vast majority have lost their natural functions and only serve as transport interchanges. Using the above economic, social, historical, and environmental criteria, forty-four territories were defined as nodal areas in Kyiv. Thirty-four already exist and ten have potential features of nodal areas (Table 1, Figure 2). However, the adjustment of urban land-use patterns to new social conditions and spatial transformations is ongoing (Sýkora \& Bouzarovski,
2012) in all parts of the city. All nodal areas perform the functions of places along the major transport routes and intersections, and also provide specific representative, communication, service, and commercial functions. The last two functions are dominant for all nodal areas; sometimes they replace representative, cultural-aesthetic, and recreational functions.

The research confirms that the main phenomena that are changing urban processes and functions and that are deforming the nodal areas' spatial structures are commercialization, verticalization, spatial unification, and homogenization. In some areas, revitalization, re-sacralization, and social polarization are taking place against the background of general trends of tertiarization, gentrification, and significant growth in Kyiv's population. The city is growing by an average of 20,000 people annually. These additions are reflected in the real estate market and create additional pressure on the city's infrastructure (Dronova \& Maruniak, 2018).

In the struggle for urban resources, new functions are displacing those considered less relevant for business or less competitive. The loss of public open spaces is evident in most of the city's nodal areas. Urban public spaces are being used for building business centres or shopping malls. One of the consequences of this commercialization is that people are leaving the traditional public places for rest and leisure on the streets and are moving inside the buildings. These spaces are experiencing a similar phenomenon over much of the rest of the world; namely, the urban landscape is becoming homogeneous and inhospitable.

There is a gentrification of certain nodal areas - for example, the luxury Arena City (Arena Siti) complex on Bessarabia Square (Bessarabs'ka ploshcha), the Diamond Hill (Daymond Khyll) apartment complex on Glory Square (Ploshcha Slavy), the Obolon Lypky (Obolons'ki Lypky) housing estate, and the renovated Central Universal Department Store of Kyiv (Tsentral'nyy universal'nyy mahazyn Kyeva, TsUM) on Kreshchatyk Street (Vulytsya Khreshchatyk) - compared with the organized markets of second-hand stores near four metro stations that contribute to the emergence of social polarization and fragmentation.

We recognize that the main driving forces behind changes in the city's image are developers with significant capital and connections with power authorities. They are ostensibly interested in making quick profits. Here we observe the manifestation of the negative sides of a neoliberal urban policy that prompts the replication of the monotonous types of spatial development and eliminates existing features of national and cultural identity. As a result, in central Kyiv's nodal areas, including protected zones of architectural monuments of world significance, 


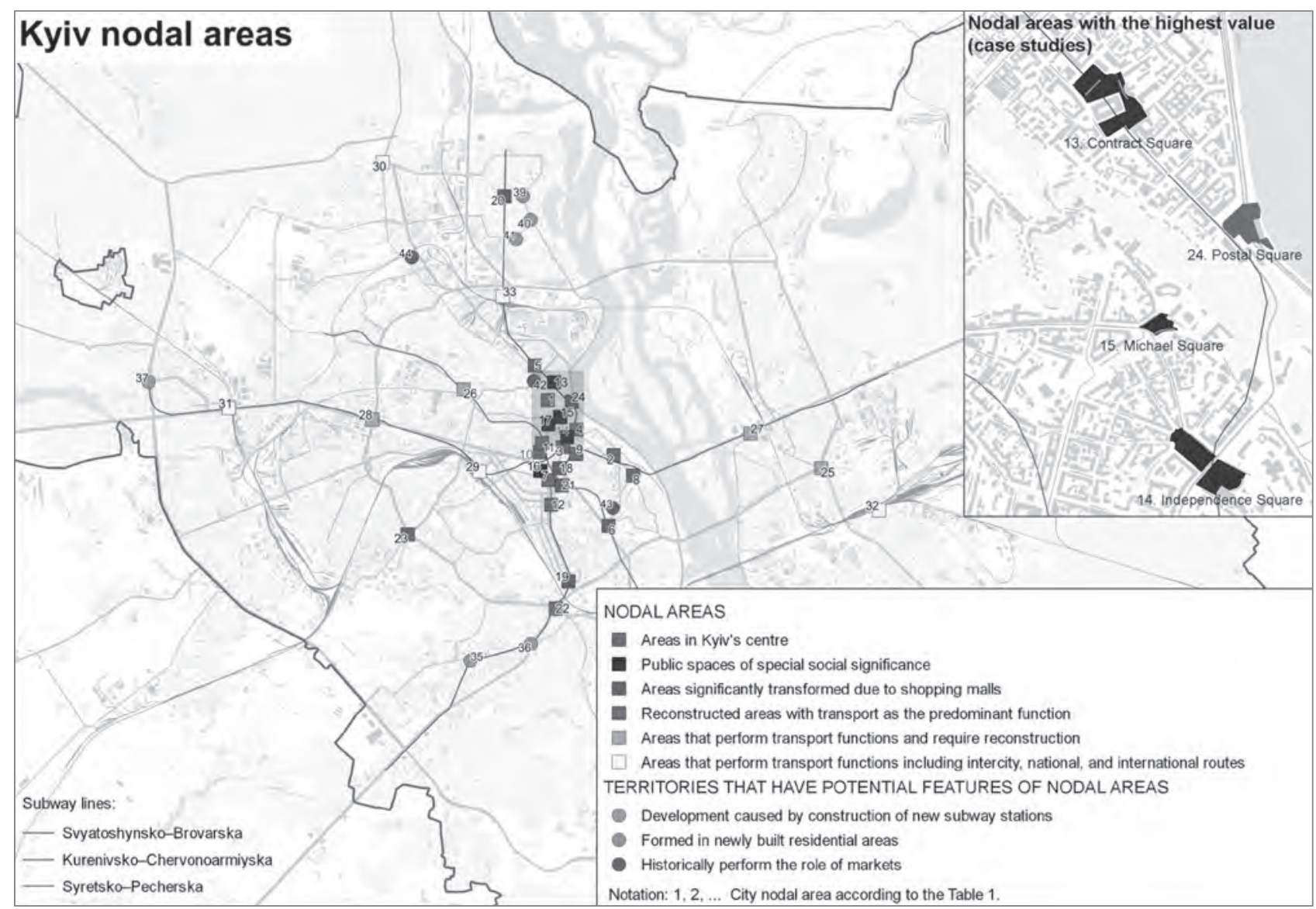

Figure 2: Nodal areas in Kyiv (illustration: Olena Dronova).

huge newly built multi-storey buildings are visually dominant. They deform the city's spatial identity, creating threats to its diversity (Al-Hamarneh et al., 2013). Such active urban development usually happens without the public being involved in the decision-making processes. Many problems have emerged and become commonplace in Kyiv in recent years: violation of the spatial structure and architectural ensembles of certain areas, destruction of green spaces, problems with sun exposure in neighbouring houses as a result of the creation of new structures, and unauthorized additions of upper floors of residential buildings. These and other problems often are met with protests by local residents.

In a spatial context, individual nodal areas represent "hybrid spatialities" (Golubchikov et al., 2013), where examples of Soviet Kyiv's modernist architecture are eclectically connected with post-Soviet high-tech skyscrapers. An example is Glory Square with the old monument of the Hotel Salute (Hotel' Salyut) and the new construction of the Diamond Hill luxury apartments. Separate territories represent a combination of architectural ensembles of the Soviet period and Kievan Rus, which are now affected by glass buildings of the globalization era on Sophia Square (Sofys'ka ploshcha) and Michael Square (Mykhaylivs'ka ploshcha).
The advantage of the globalization processes is that Kyiv's citizens, guided by what they observe from numerous examples in other regions of the world, are beginning to realize the importance of engaging in the decision-making processes related to ongoing spatial, economic, and social urban development. The increased number, scale, and variety of such social movements in Kyiv reflects an increase in the level of public awareness as well as a consciousness of citizens regarding their responsibility for the city's future (Dronova \& Maruniak, 2018).

In carrying out this research, we observed that the majority of Kyiv's nodal areas are influenced by global neoliberal processes. However, there are differences in the observable impacts of such transformations. Considering these differences in defining the criteria of nodal areas and their social and cultural value, the following types can be distinguished in Kyiv (Table 1, Figure 2):

- Areas in Kyiv's centre;

- Public spaces of special social significance;

- Areas significantly transformed due to shopping malls;

- Reconstructed areas with transport as the predominant function;

- Areas with transport functions that require reconstruction; and 
Table 1: Main city nodal areas of Kyiv: criteria and value

\begin{tabular}{|c|c|c|c|c|c|c|c|}
\hline \multirow[t]{2}{*}{ Nodal area } & \multicolumn{7}{|l|}{ Criteria } \\
\hline & $\begin{array}{l}\text { Transport } \\
\text { accessibility }\end{array}$ & $\begin{array}{l}\text { Political } \\
\text { gatherings }\end{array}$ & $\begin{array}{l}\text { Festive or } \\
\text { social events; } \\
\text { sports com- } \\
\text { petitions }\end{array}$ & $\begin{array}{l}\text { Cultural, historical, } \\
\text { sacred, or aesthetic } \\
\text { monuments and } \\
\text { artefacts }\end{array}$ & $\begin{array}{l}\text { Pedestrian zones with } \\
\text { cafes, art shops, and places } \\
\text { for socializing, recreation, } \\
\text { and relaxation }\end{array}$ & $\begin{array}{l}\text { Parks, squares, } \\
\text { elements of } \\
\text { unique natu- } \\
\text { ral landscapes }\end{array}$ & $\begin{array}{l}\text { Value } \\
\text { index }\end{array}$ \\
\hline \multicolumn{8}{|l|}{ Areas in Kyiv's centre } \\
\hline $\begin{array}{l}\text { 1. Andrew's Descent (Andriyivs'kyy } \\
\text { uzviz) }\end{array}$ & $1^{*}$ & 0 & 1 & 2 & 3 & 1 & 1.3 \\
\hline $\begin{array}{l}\text { 2. Arsenal Square (Arsenal'na plos- } \\
\text { hcha) and Maria Park (Mariyins'kyy } \\
\text { park) }\end{array}$ & 2 & 3 & 1 & 2 & 0 & 2 & 1.7 \\
\hline $\begin{array}{l}\text { 3. Khreshchatyk Street (Vulytsya } \\
\text { Khreshchatyk) }\end{array}$ & 2 & 1 & 2 & 2 & 2 & 0 & 1.5 \\
\hline $\begin{array}{l}\text { 4. European Square (Yevropeys'ka } \\
\text { ploshcha) }\end{array}$ & 1 & 1 & 1 & 1 & 0 & 2 & 1 \\
\hline $\begin{array}{l}\text { 5. Square near the October (Zhov- } \\
\text { ten') movie theatre }\end{array}$ & 1 & 0 & 1 & 1 & 1 & 1 & 0.8 \\
\hline $\begin{array}{l}\text { 6. Lesya Ukrainka Square } \\
\text { (Ploshcha Lesi Ukrayinky) }\end{array}$ & 2 & 0 & 0 & 0 & 0 & 0 & 0.3 \\
\hline $\begin{array}{l}\text { 7. Leo Tolstoy Square (Ploshcha } \\
\text { L'va Tolstoho) }\end{array}$ & 2 & 0 & 1 & 1 & 0 & 0 & 0.7 \\
\hline 8. Glory Square (Ploshcha Slavy) & 3 & 1 & 1 & 1 & 0 & 2 & 1.3 \\
\hline $\begin{array}{l}\text { 9. Ivan Frank Square (Ploshcha } \\
\text { Ivana Franka) }\end{array}$ & 1 & 0 & 1 & 1 & 1 & 1 & 0.8 \\
\hline $\begin{array}{l}\text { 10. Theatre Square (Teatral'na } \\
\text { ploshcha) }\end{array}$ & 2 & 0 & 1 & 1 & 1 & 1 & 1 \\
\hline $\begin{array}{l}\text { 11. The area around the Golden } \\
\text { Gate (Zoloti vorota) }\end{array}$ & 2 & 0 & 1 & 2 & 1 & 1 & 1.2 \\
\hline $\begin{array}{l}\text { 12. Trinity Square (Troyits'ka plo- } \\
\text { shcha) }\end{array}$ & 3 & 0 & 3 & 1 & 0 & 0 & 1.2 \\
\hline \multicolumn{8}{|c|}{ Public spaces of special social significance } \\
\hline $\begin{array}{l}\text { 13. Contract Square (Kontraktova } \\
\text { ploshcha) }\end{array}$ & 3 & 1 & 4 & 3 & 2 & 2 & 2.5 \\
\hline $\begin{array}{l}\text { 14. Independence Square (May- } \\
\text { dan Nezalezhnosti) }\end{array}$ & 3 & 4 & 2 & 2 & 3 & 0 & 2.3 \\
\hline $\begin{array}{l}\text { 15. Michael Square } \\
\text { (Mykhaylivs'ka ploshcha) }\end{array}$ & 1 & 1 & 3 & 3 & 2 & 3 & 2.2 \\
\hline $\begin{array}{l}\text { 16. Taras Schevchenko Park } \\
\text { (Park imeni Tarasa Shevchenka) }\end{array}$ & 3 & 2 & 3 & 2 & 1 & 1 & 2 \\
\hline $\begin{array}{l}\text { 17. Sophia Square (Sofiys'ka plo- } \\
\text { shcha) }\end{array}$ & 1 & 2 & 3 & 4 & 1 & 0 & 1.8 \\
\hline \multicolumn{8}{|c|}{ Areas significantly transformed due to shopping malls } \\
\hline $\begin{array}{l}\text { 18. Besaarabi Square (Bessarabs'ka } \\
\text { ploshcha) }\end{array}$ & 1 & 0 & 1 & 1 & 0 & 0 & 0.5 \\
\hline $\begin{array}{l}\text { 19. Lybid Sqaure (Lybids'ka } \\
\text { ploshcha) }\end{array}$ & 3 & 0 & 1 & 0 & 0 & 0 & 0.7 \\
\hline $\begin{array}{l}\text { 20. Minsk Square (Mins'ka plos- } \\
\text { hcha) }\end{array}$ & 3 & 0 & 0 & 0 & 0 & 0 & 0.5 \\
\hline $\begin{array}{l}\text { 21. Sports Square (Sportyvna } \\
\text { ploshcha) }\end{array}$ & 2 & 0 & 1 & 0 & 0 & 0 & 0.5 \\
\hline
\end{tabular}




\begin{tabular}{|c|c|c|c|c|c|c|c|}
\hline \multirow[t]{2}{*}{ Nodal area } & \multicolumn{7}{|l|}{ Criteria } \\
\hline & $\begin{array}{l}\text { Transport } \\
\text { accessibility }\end{array}$ & $\begin{array}{l}\text { Political } \\
\text { gatherings }\end{array}$ & $\begin{array}{l}\text { Festive or } \\
\text { social events; } \\
\text { sports com- } \\
\text { petitions }\end{array}$ & $\begin{array}{l}\text { Cultural, historical, } \\
\text { sacred, or aesthetic } \\
\text { monuments and } \\
\text { artefacts }\end{array}$ & $\begin{array}{l}\text { Pedestrian zones with } \\
\text { cafes, art shops, and places } \\
\text { for socializing, recreation, } \\
\text { and relaxation }\end{array}$ & $\begin{array}{l}\text { Parks, squares, } \\
\text { elements of } \\
\text { unique natu- } \\
\text { ral landscapes }\end{array}$ & $\begin{array}{l}\text { Value } \\
\text { index }\end{array}$ \\
\hline \multicolumn{8}{|c|}{ Reconstructed areas with transport as the predominant function } \\
\hline $\begin{array}{l}\text { 22. Demiyivka Square (Demiyivs'ka } \\
\text { ploshcha) }\end{array}$ & 4 & 0 & 0 & 0 & 0 & 0 & 0.7 \\
\hline $\begin{array}{l}\text { 23. Sevastopol Square } \\
\text { (Sevastopol's'ka ploshcha) }\end{array}$ & 2 & 0 & 0 & 0 & 0 & 0 & 0.3 \\
\hline $\begin{array}{l}\text { 24. POstal Square (Poshtova } \\
\text { ploshcha) }\end{array}$ & 3 & 0 & 2 & 3 & 2 & 4 & 2.3 \\
\hline \multicolumn{8}{|c|}{ Areas with transport functions that require reconstruction } \\
\hline $\begin{array}{l}\text { 25. Darnytsya (Darnyts'ka } \\
\text { ploshcha) }\end{array}$ & 3 & 0 & 0 & 0 & 0 & 0 & 0.5 \\
\hline $\begin{array}{l}\text { 26. Lukyanivka Square } \\
\text { (Luk'yanivs'ka ploshcha) }\end{array}$ & 3 & 0 & 0 & 1 & 0 & 0 & 0.7 \\
\hline $\begin{array}{l}\text { 27. The area around the Left Bank } \\
\text { (Livoberezhna) metro station }\end{array}$ & 3 & 0 & 0 & 0 & 0 & 0 & 0.5 \\
\hline $\begin{array}{l}\text { 28. The area around the Shulyav- } \\
\text { ka (Shulyavs'ka) metro station }\end{array}$ & 2 & 0 & 0 & 0 & 0 & 0 & 0.3 \\
\hline \multicolumn{8}{|c|}{ Areas with transport functions, including intercity, national, and international routes } \\
\hline $\begin{array}{l}\text { 29. Central Railway Station Square } \\
\text { (Vokzal'na ploshcha) }\end{array}$ & 3 & 0 & 0 & 1 & 0 & 0 & 0.7 \\
\hline $\begin{array}{l}\text { 30. Taras Shevchenko Square } \\
\text { (Ploshcha Tarasa Shevchenka) }\end{array}$ & 2 & 0 & 0 & 0 & 0 & 0 & 0.3 \\
\hline $\begin{array}{l}\text { 31. Brest Heroes Square (Ploshcha } \\
\text { Heroyiv Bresta) }\end{array}$ & 3 & 0 & 0 & 0 & 0 & 0 & 0.5 \\
\hline $\begin{array}{l}\text { 32. Darnytsya Railway Station } \\
\text { Square (Pryvokzal'na ploshcha) }\end{array}$ & 2 & 0 & 0 & 0 & 0 & 1 & 0.5 \\
\hline $\begin{array}{l}\text { 33. The area around the Pochayna } \\
\text { metro station }\end{array}$ & 3 & 0 & 1 & 0 & 0 & 0 & 0.7 \\
\hline $\begin{array}{l}\text { 34. The area around the Vydu- } \\
\text { bychi metro station }\end{array}$ & 3 & 0 & 0 & 0 & 0 & 0 & 0.5 \\
\hline \multicolumn{8}{|c|}{ Territories that have potential features of nodal areas } \\
\hline \multicolumn{8}{|c|}{ a. Development caused by new subway stations } \\
\hline \multicolumn{8}{|c|}{$\begin{array}{l}\text { 35. Amur Square (Amurs'ka ploshcha); } 36 \text {. Holosiyiv Square (Holosiyivs'ka ploshcha); } 37 \text {. The exit from the Akademmistechko subway station; } \\
\text { 38. The exit from the Kharkiv (Kharkivs'ka) subway station }\end{array}$} \\
\hline \multicolumn{8}{|c|}{ b. Formed in newly built residential areas } \\
\hline \multicolumn{8}{|c|}{$\begin{array}{l}\text { 39. Mykhaylo Zahorodniy Square (Ploshcha Mykhayla Zahorodn'oho); 40. Santiago Square (Ploshcha Sant'yaho-de-Chyli); 41. Obolon Square } \\
\text { (Obolons'ka ploshcha) }\end{array}$} \\
\hline \multicolumn{8}{|c|}{ c. Historically perform the role of markets } \\
\hline
\end{tabular}

42. Grain Market Square (Zhytn'otorz'ka ploshcha); 43. Pechersk Square (Pechers'ka ploshcha); 44. Peter and Paul Square (Petropavlivs'ka ploshcha)

Note: ${ }^{*}$ Criteria display: $0=$ absent, $1=$ low, $2=$ satisfactory, $3=$ high, $4=$ very high

- Areas with transport functions, including intercity, national, and international routes.

On the basis of observations, using data on the intersection of various types of transport, information on the frequency of various social and political gatherings at different scales, planning documentation on pedestrian areas and open public places, and the presence of unique architectural and natural landscapes, we constructed an index or score for thirty-four existing nodal areas and took into account ten potential ones (Table 1). The model aids in determining their functional and spatial patterns (Figure 2). It also identifies those nodes with the highest social significance: Contract Square, Postal Square, and Independence Square. To illustrate the neoliberal 


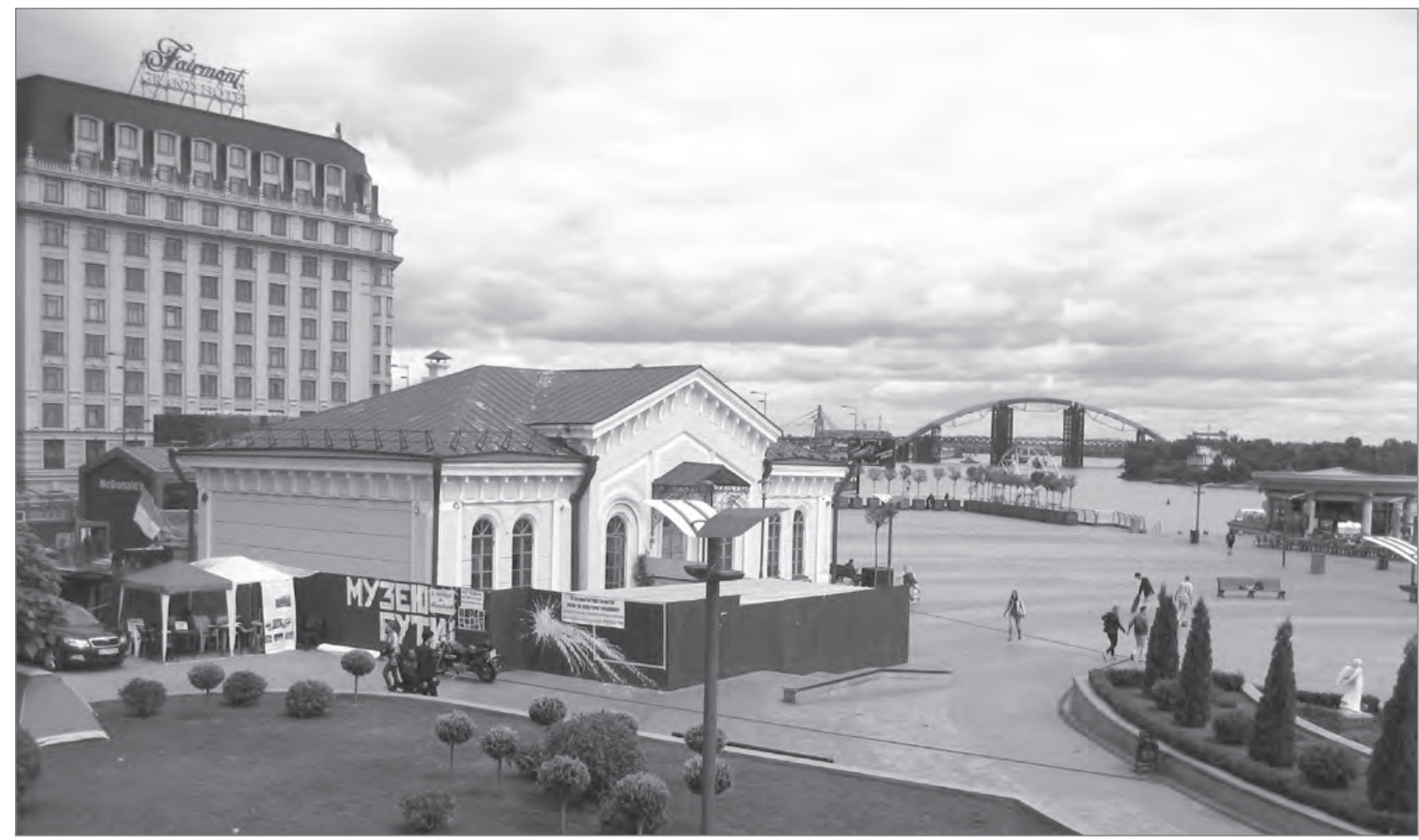

Figure 3: Postal Square, Kyiv, Ukraine. The sign on the fence reads "There will be a museum!" (photo: Olena Dronova).

processes described above, we next examine the current state and transformations of these three areas.

\section{Kyiv nodal areas: three case studies}

The areas in the central part of Kyiv - Old Kyiv (Staryy Kyiv), Podil, and Pechersk (Pechers' $k$ ) - have a huge potential for development due to highly aesthetic buildings, green areas in close proximity, and cultural and historical heritage. However, today they are heavily affected by the loss of primary functions. Their space is occupied by shopping and entertainment centres, hotels, parking lots, temporary structures, outdoor advertising facilities, and unauthorized trade. The more these nodal areas are developed and occupied, the more green areas diminish. At the beginning of the twenty-first century, Kyiv was at the top of the list as one of the greenest cities in Europe; today it holds thirtieth place with an index of 32.33 out of 100 (European Green City Index, 2015).

Contract Square (Kontraktova ploshcha) is a former high-profile marketplace and the one of the city's oldest nodal areas. Today it is considered a slowly revitalizing public space with numerous conflicts. However, it remains the only space that still (at least partially) retains its identity as a free "intellectual" public space. The historical building of Kyiv-Mohyla Academy located on the square increases its value as a nodal area. However, the square is often perceived as an ordinary object of investment in the Kyiv real estate development, a place to exploit its spatial identity, and a convenient location and significant symbolic capital of historical importance. Quarters around the square are gradually witnessing the construction of large office centres and expensive hotels that are not historically inherent to this area. Elsewhere, public space is actively being privatized and used as outdoor terraces for expensive restaurants and office parking lots. Currently, and as a result of numerous public actions, the area is gradually emerging as a comfortable pedestrian space with art workshops, weekend markets for exclusive locally made goods, cafes, and places for socializing, recreation, and relaxation.

Postal Square (Poshtova ploshcha) has also undergone largescale transformations. As a major transportation hub and with a powerful historical heritage, it is one of the most interesting and best-known areas in Kyiv. The latest reconstruction started in the summer of 2015. The idea is that people can have access to the banks of the Dnieper River by avoiding the motorway. Increasingly more European cities are seeking ways to open themselves to the river. Conceptually, the project has many advantages for Kyiv, but there are many points of debate in planning and implementation. The area is still inaccessible to people with disabilities, and the ramps that have been built do not meet contemporary standards. There are problems with greening and planting. Following the construction of a restaurant complex and a shopping mall, which are planned on the 

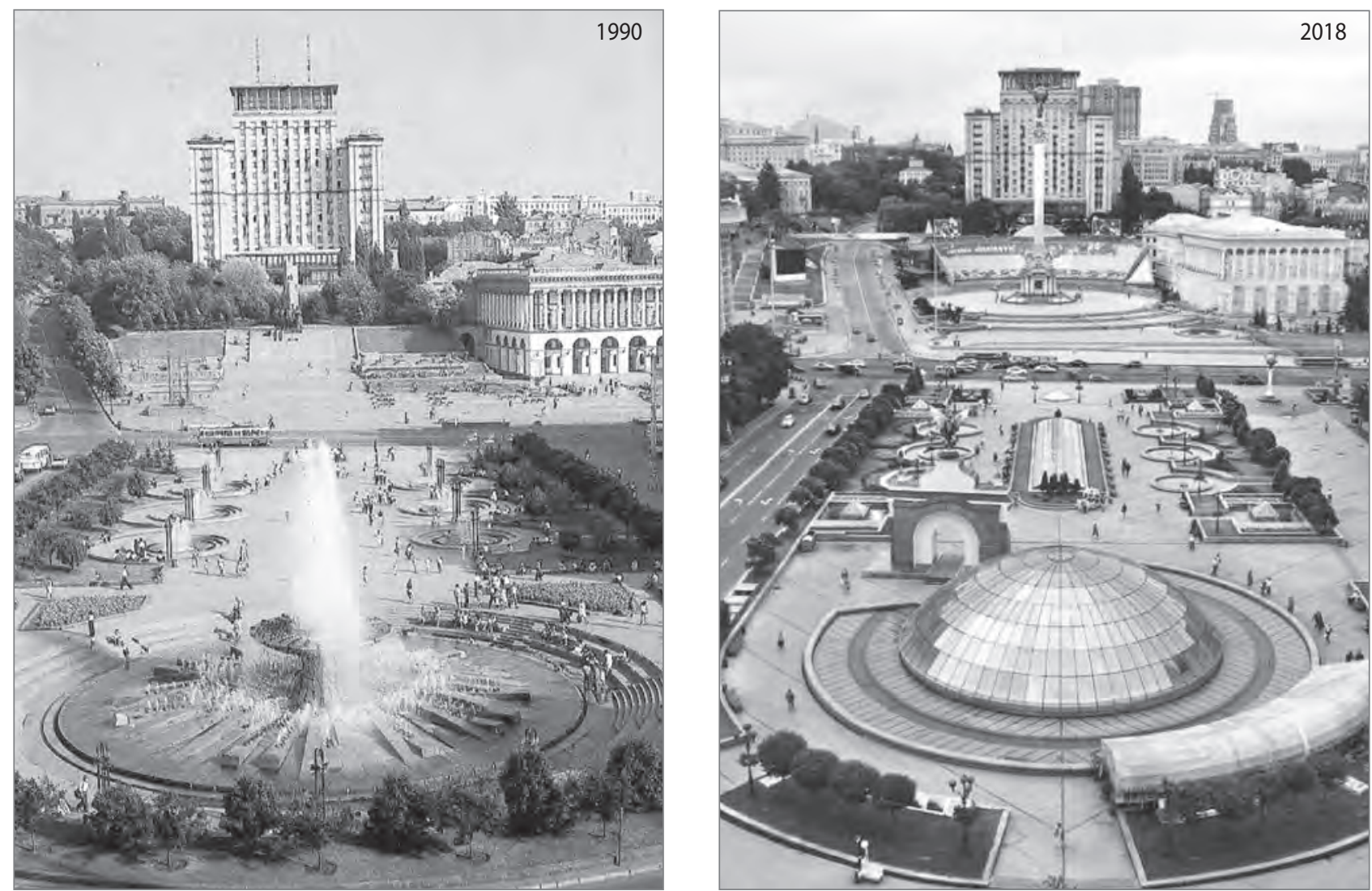

Figure 4: Independence Square: before and after the 2001 reconstruction (source: Internet 1).

site of the river station and underground (note the dominance of economic priorities), the area now faces enormous problems with the need for more parking spaces.

Another issue of major social and cultural significance is that archaeologists have excavated a unique ancient city of Kievan Rus (eleventh to twelfth century) in the process of constructing a shopping mall. Current debate continues among the public, the municipality, and the developer about the possibility of creating a museum instead of a shopping centre. Public activists physically blocked access to the construction spot, demanding the preservation of artefacts (Figure 3).

Another important nodal area is Independence Square (Maydan Nezalezhnosti). During the twentieth century it experienced a number of reconstructions. After gaining independence, the desire to turn Kyiv into a European city prompted the city's administration to begin reconstruction of Khreshchatyk Street and adjacent areas, including Independence Square. In 2001, reconstruction of the square was carried out and some monuments - in particular, the Independence Monument were erected. The underground Globus shopping mall opened the same year despite repeated violation of construction and sanitary regulations. According to many experts, it would be more reasonable to preserve the green zones and archaeological finds that were discovered during the reconstruction process and turn this area into a museum of Kyiv's history, as was once planned (Figure 4).

Despite changes in the aesthetic and functional plan related to the general commercialization of space, the nodal area of Independence Square remains a place of national political activity. This square was the heart of the 2004 Orange Revolution and the 2014 Uprising of Dignity (a.k.a. Euromaidan) with protests across Ukraine, and it is a place in which the processes of national ideas and freedoms are localized and intersect. These events occurred despite the intentions of the former authorities to treat it only as a place for New Year's celebrations (Figure 5). This observation confirms self-development as a key feature of the nodal area.

Some squares that historically performed and still perform the functions of markets retain the features of nodal areas: Grain Market Square (Zhytnotorz'ka ploshcha), Pechersk Square (Pecherska ploshcha), and Peter and Paul Square (Petropavlivs'ka ploshcha). Others were formed in the second half of the twentieth century and the beginning of twenty-first century in newly built residential areas: Mykhaylo Zahorodniy Square (Ploshcha Mykhayla Zahorodn'oho), Santiago Square (Ploshcha Sant'yaho-de-Chyli), and Obolon Square (Obolons'ka ploshcha). Terri- 


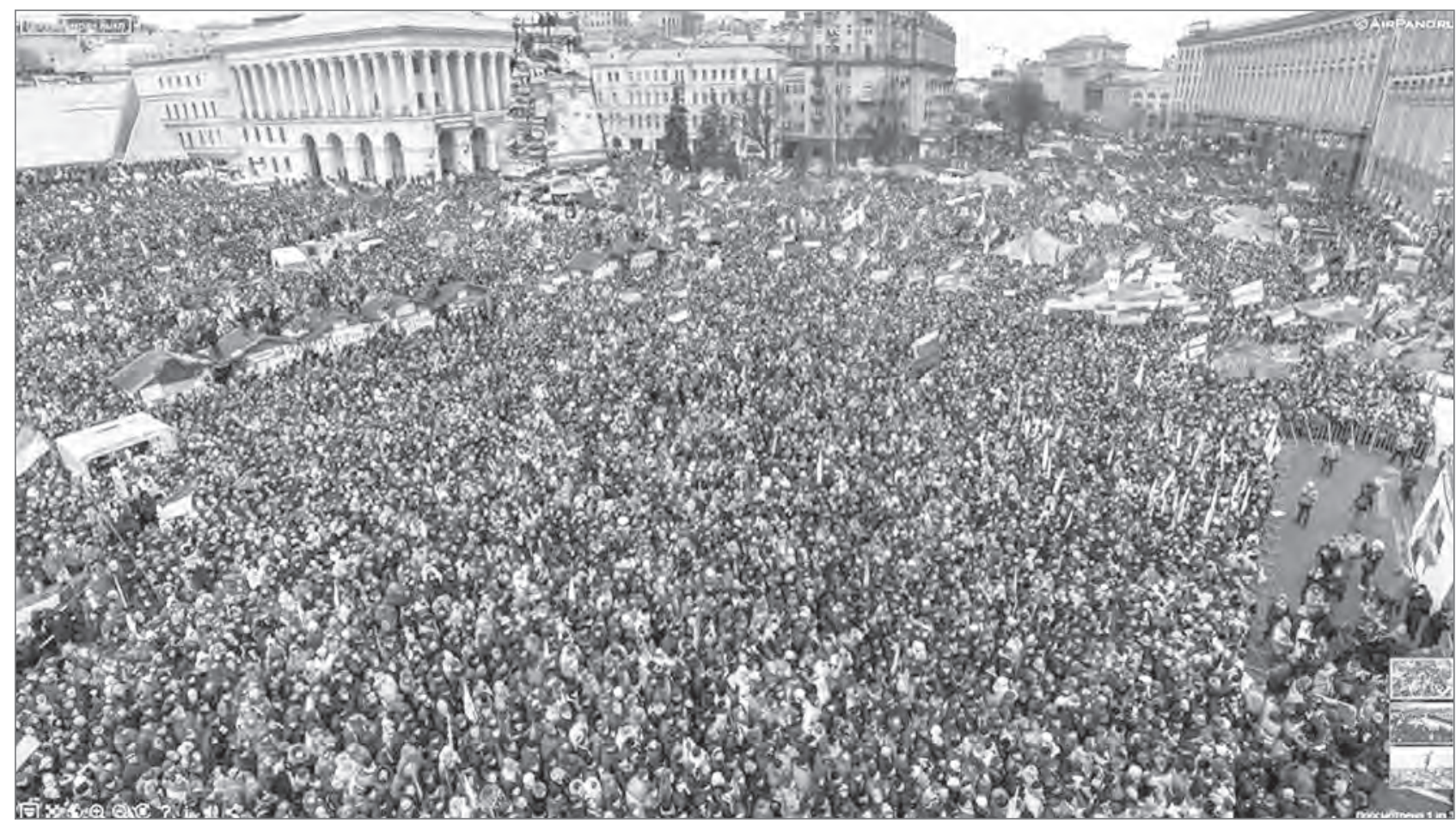

Figure 5: Independence Square, the Uprising of Dignity (Euromaidan) in Kyiv, 2014 (source: Internet 2).

tories that were developed due to the construction of new subway stations - Amur Square (Amurs'ka ploshcha) and Holosiyiv Square (Holosiyivs'ka ploshcha) - as well as the exits from the Akademmistechko and Kharkiv (Kharkivs'ka) subway stations also have features of nodal areas. A number of Kyiv squares that were formed at the intersection of newly paved streets were not included in the list of existing nodal areas: Ankara Square (Ploshcha Ankary), Panteleimon Kulish Square (Ploshcha Panteleymona Kulisha), Kerch Square (Kerchens'ka ploshcha), Volgograd Square (Volhohrads'ka ploshcha), and Valeriy Marchenko Square (Ploshcha Valeriya Marchenka). Today, they only perform the function of road intersections and do not attract residents pursing leisure activities. We assume that eventually these territories will acquire additional functions due to their transport accessibility. At the same time, and in the case of preserving current trends, the space of these areas is under threat of being transformed into a routine landscape of shopping centres, kiosks, and shops on wheels.

\section{Discussions and conclusions}

Significant transformations of post-Soviet urban space are occurring in many eastern European countries today. Cities are avoiding centralized urban planning and design and implementing many of the same neoliberal urbanization mechanisms observed in Ukrainian cities (Sosnova, 2011). This transformation has triggered significant changes in urban functions and in the characters of cities themselves. To understand and track those transformations, we considered structural elements observed in a city. Today we note that nodal areas have been transformed from the perceptual category associated with Lynch into processes that describe human livelihood and landscape changes at all scales. This change is a part of the fundamental topological structure of spaces associated with movement and visibility. Some nodal areas - particularly historical centres of cities and territories that are memorable for residents due to the events that happened there and squares that are distinct due to sacral, architectural, and educational institutions located there - play a role as symbolic focal points of the city and are associated with the city's spatial identity.

Although spatial identity should be one of the priorities in new construction in post-communist cities, it is often relativized and suppressed compared to other aspects of the urban environment (Kuvač \& Schwai, 2017). In places where functions and processes are concentrated, the constant replacement of functions is most noticeable and observable, as well as the corresponding reorganization of the urban structure. Under neoliberal globalization processes, the city nodal areas become the most attractive for various activities and, in the event of a constant change of actors and priorities, they change dynamically and dramatically. Of all urban spaces, they are the most vulnerable. Additional research focusing on transformations can now examine how the processes of commercialization, tertiarization, verticalization, and selective deregulation of urban 
space lead to the emergence of spatial homogenization and how nodal areas themselves are losing their original functions and identities.

As Lerner argues, in order to restore the soul of the city, it is necessary to encourage people to create places of meetings and to ensure that every urban function becomes a catalyst for such interaction. The more the city is perceived as an integration of processes and functions that bring together the rich and the poor, and the young and the elderly, the more places for meetings or encounters will be created with the result being a more vibrant city (Lerner, 2014). Design, functionality, protection of authentic buildings, and elusive features such as the spirit and the energy of the nodal areas are of great importance in creating the atmosphere of the city as a whole. Together they form the "face of the city". The features and criteria presented in this study make it possible to clearly distinguish nodal areas from other urban structures. The analysis of current nodal area transformations in Kyiv and their changes under the influence of neoliberal globalization processes demonstrate the need to restore social priorities. Attention should be paid to issues regarding their allocation, functioning, and development not only at the theoretical and cognitive levels, but also at administrative levels. Concepts of urban development at district and lower levels involving the public in shaping the city's image will help ensure that nodal areas are comfortable and meaningful for people's lives. These and other issues, including the application of integrated urban development approaches, require ongoing research.

\section{Olena Dronova}

Taras Shevchenko National University of Kyiv, Faculty of Geography, Department of Economic and Social Geography, Kyiv, Ukraine

E-mail: olena.dronova@gmail.com

\section{Stanley D. Brunn}

University of Kentucky, Department of Geography, Lexington, KY, USA

E-mail: brunn@uky.edu

\section{Acknowledgements}

The authors gratefully acknowledge the support provided by Dmytro Poleshko in conducting field surveys and gathering data.

\section{References}

Alaev, E. (1977) Economico-geographicheskaya terminologia. Moscow Mysl.

Al-Hamarneh, A. (2011) Neoliberal urbanization economy and processes: E.g. New Cairo. Paper presented at the CEDEJ-GTZ seminar "Fabrique urbaine et développement durable au Caire et en Egypte," 23 January, Cairo, Egypt. Typescript.
Al-Hamarneh, A., Margraff, J. \& Doronova, O. (2013) Goroda v usloviah neoliberalnogo razvitia obshchestva: tendencii ne primere gorodov Dubai i Kiev. Ukrainian Geographical Journal, 1, pp. 35-39. DOI: 10.15407/ugz2013.01.035

Appleyard, D. (1969) Why buildings are known. Environment and Behavior, 1(2), pp. 131-156. DOI: 10.1177/001391656900100202

Balibrea, M. P. (2001) Urbanism, culture and the post-industrial city: Challenging the "Barcelona model." Journal of Spanish Cultural Studies, 2(2), pp. 187-210. DOI: 10.1080/14636200120085174

Birch, K. \& Mykhnenko, V. (eds.) (2010) The rise and fall of neoliberalism: The collapse of an economic order? London: Zed.

Brenner, N. \& Theodore, N. (2002) Cities and the geographies of "actually existing neoliberalism." Antipode, 34(3), pp. 349-379. DOI: $10.1111 / 1467-8330.00246$

Brenner, N. \& Theodore, N. (eds.) (2003) Spaces of neoliberalism: Urban restructuring in North America and western Europe. Malden, Blackwell Publishing.

Brenner, N. \& Schmid, C. (2014) The urban age in question, In: Brenner, N. (ed.) Implosions/explosions. Towards a study of planetary urbanization, pp. 310-337. Berlin, Jovis. DOI: 10.1111/1468-2427.12115

Castells, M. (1977) The urban question. A Marxist approach. London, Edward Arnold.

Dalton, R. \& Bafna, S. (2003) The syntactical image of the city: A reciprocal definition of spatial elements and spatial syntaxes. In: Proceedings of the 4th International space syntax symposium, pp. 59.1-59.22. London, Space Syntax.

Dronova, O. \& Al-Hamarneh, A. (2013) Neoliberalnye podhody k gorodskomu upravleniu I osobennosti ih proyavlenia v prostranstvennom razvitii Kieva. Economic and Social Geography, 1(66), pp. 66-78.

Dronova, O. \& Maruniak, E. (2018) Changing the symbolic language of the urban landscape: Post-socialist transformation in Kyiv. In: Brunn, S. D. \& Kehrein, R. (eds.) Handbook of the changing world language map. Dordrecht, Springer.

Dronova, O. \& Poleshko, D. (2017) Funktsionalni i prostorovi transformatsii vuzlovyzh terytoriy Kyeva. In: Mezentsev, K., Olijnyk, Y. \& Mezentseva, N. (eds.) Urban Ukraine: In epicenter of spatial changes, pp. 211-227. Kyiv, Phenix.

Eugenio, M. \& Ratti, C. (2009) A digital image of the city: 3D isovists in Lynch's urban analysis, Environment and Planning B: Planning and Design, 36(5), pp. 837-853. DOI: 10.1068/b34144t

European Green City Index (2015) Economist Intelligence Unit. Available at: http://www.siemens.com/entry/cc/features/greencityindex_international/all/en/pdf/report_en.pdf (accessed 18 May 2018).

Florida, R., Adler, P. \& Mellander, C. (2017) The city as innovation machine. Regional Studies, 51(1), pp. 86-96. DOI: 10.1080/00343404.2016. 1255324

Foucault, M. (1967) Andere Räume. In: B. Karlheinz (ed.) Aisthesis: Wahrnehmung heute oder Perspektiven einer anderen Ästhetik. Leipzig, Reclam.

Friedmann, J. \& Wolff, G. (1982) World city formation: An agenda for research and action. International Journal of Urban and Regional Research, 6(3), pp. 309-344. DOI: 10.1111/j.1468-2427.1982.tb00384.x

Friedmann, J. (1986) The world city hypothesis. Development and Change, 17(1), pp. 12-50. DOI: 10.1111/j.1467-7660.1986.tb00231.x

Geddes, P. (1915) Cities in evolution: An introduction to the town planning movement and to the study of civics. London, Williams \& Norgate. 
Golledge, R. \& Spector, A. (1978) Comprehending the urban environment: Theory and practice. Geographical Analysis, 10(4), pp. 403-426. DOI: 10.1111/j.1538-4632.1978.tb00667.x

Golubchikov, O., Badyina, A. \& Makhrova, A. (2014) The hybrid spatialities of transition: Capitalism, legacy and uneven urban economic restructuring. Urban Studies, 51(4), pp. 617-633. DOI: 10.1177/0042098013493022

Haken, H. \& Portugali, J. (2003) The face of the city is its information. Journal of Environmental Psychology, 23(4), pp. 385-408. DOI: 10.1016/S0272-4944(03)00003-3

Hall, P. (1993) The changing role of capital cities: Six types of capital city. In: Taylor, J. (ed.) Capital cities - International perspective, pp. 69-84. Ottawa, Carleton University Press.

Harvey, D. (1973) Social justice and the city. London, Edward Arnold.

Harvey, D. (1989) From managerialism to entrepreneurialism: The transformation in urban governance in late capitalism. Geografiska Annaler, 71(1), pp. 3-17. DOI: 10.1080/04353684.1989.11879583

Hospers, G. (2010) Lynch's The image of the city after 50 years: City marketing lessons from an urban planning classic. European Planning Studies, 18(12), pp. 2073-2081. DOI: 10.1080/09654313.2010.525369

Internet 1: http://www.archdesignfoto.com/ (accessed 29 June 2018).

Internet 2: https://ukrainesolidaritycampaign.org (accessed 29 June 2018).

Jacobs, J. (1961) The death and life of great American cities. New York, Vintage.

Jacobs, J. (1970) The economy of cities. London, Vintage.

Jessop, B. (1997) The entrepreneurial city: Re-imaging localities. Redesigning economic governance, or restructuring capital? In: Jewson, N. \& MacGregor, S. (eds.) Transforming cities. Contested governance and new spatial divisions, pp. 28-41. London, Routledge.

Jiang, B. (2012) Computing the image of the city. In: Campagna, M., De Montis, A., Isola, F., Pira, C. \& Zoppi, C. (eds.) Proceedings of the 7th International Conference on Informatics and Urban and Regional Planning, pp. 111-121. Milan, FrancoAngeli.

Križnik, B. (2011) Selling global Seoul: Competitive urban policy and symbolic reconstruction of cities. Revija za sociologiju, 41(3), pp. 291312. DOI: $10.5613 /$ rzs.41.3.2

Križnik, B. (2018) Transformation of deprived urban areas and social sustainability: A comparative study of urban regeneration and urban redevelopment in Barcelona and Seoul. Urbani izziv, 29(1), pp. 83-95. DOI: 10.5379/urbani-izziv-en-2018-29-01-003

Kuvač, I. \& Schwai, M. (2017) Three elements in the construction of spatial identities in Mađir (Banjaluka, Bosnia and Herzegovina) and Ilsvika (Trondheim, Norway) neighbourhoods. Urbani izziv, 28(1), pp. 83-95. DOI: 10.5379/urbani-izziv-en-2017-28-01-001

Lappo, G. (1997) Geographia gorodov: Uchebnoe posobie. Moscow, Vlados.

Lefebvre, H. (1968) Le droit à la ville. Paris, Editions Anthropos.

Lefebvre, H. (1970) La révolution urbaine. Paris, Gallimard.

Lefebvre, H. (1974) La production de l'espace, Paris, Editions Anthropos.

Léautier, F. (ed.) (2006) Cities in a globalizing world: Governance, performance, and sustainability. Washington, DC, World Bank Publications. DOI: 10.1596/978-0-8213-6553-3

Lerner, J. (2014) Urban acupuncture. Washington, DC, Island Press. DOI: 10.5822/978-1-61091-584-7
Lynch, K. (1960) The image of the city. Cambridge, MA, MIT Press.

Marcuse, P. \& Van Kempen, R. (2000) "Introduction" in globalizing cities: A new spatial order? Oxford, Blackwell Publishing. DOI: 10.1002/9780470712887

Maruniak, E. (2007) Globalizatsia ta ii vplyv na rozvytok regioniv Ukrainy. Kyiv, Referat.

Maruniak, E. (2013) Reactsia gorodskogo prostranstva na vyzovy globalizatsii. In: Rudenko, L. (ed.) Changes of urban space in Ukraine, pp. 21-34. Kyiv, Referat.

Matlovic, R., Ira, V., Kores, P. \& Ondos, S. (2009) Urban structures and their transformation (the contribution of Slovak geography). In: Ira, V. \& Lacika, J. (eds.) Slovak geography at the beginning of the 21st century (= Geographia Slovaca, 26), pp. 71-99.

Mezentsev, K. \& Mezentseva, N. (2012) Prostranstvennye socialno-economicheskie izmenenia v Kieve i aglomeratsii. Socio-Economic Geography. Vestnik ARGO, Rostov o/D. 1, pp. 109-123.

Mezentsev, K., Pidgrushnyi, G. \& Mezentseva, N. (2015) Challenges of the post-Soviet development of Ukraine: Economic transformations, demographic changes and socio-spatial polarization. In: Henn, S., Lang, T., Sgibnev, W. \& Ehrlich, K. (eds.) Understanding geographies of polarization and peripheralization. Perspectives from central and eastern Europe and beyond, pp. 252-269. London, Palgrave Macmillan. DOI: $10.1057 / 978113741508014$

Mezentseva, N. (2017) Publichni prostory Kyeva: modeli ta suchasni transformatsii. In: Mezentsev, K., Olijnyk, Y., \& Mezentseva, N. (eds.) Urban Ukraine: In epicenter of spatial changes, pp. 185-110. Kyiv, Phenix.

Morello, E. \& Ratti, C. (2009) A digital image of the city: 3D isovists in Lynch's urban analysis. Environment and Planning B: Planning and Design, 36(5), pp. 837-853. DOI: 10.1068/b34144t

Moulaert, F. (2000) Globalization and integrated area development in European Cities. Oxford, Oxford University Press.

Moulaert, F., Swyngedouw, E. \& Rodriguez, A. (2001a) Large-scale urban development projects and local governance: From democratic urban planning to besieged local governance. Geographische Zeitschrift, 89(2-3), pp. 71-84

Moulaert, F., Swyngedouw, E. \& Rodriguez, A. (2001b) Social polarization in metropolitan areas: The role of new urban policy. European Urban and Regional Studies, 8(2), pp. 99-102. DOI: 10.1177/096977640100800201

Mumford, L. (1961) The city in history: Its origins, its transformations, and its prospects. New York, Harcourt, Brace \& World.

Norberg-Schulz, C. (1971) Existence, space and architecture. New York Praeger.

Norberg-Schulz, C. (1980) Genius loci: Towards a phenomenology of architecture. London, Academy Editions.

Nudelman, V. (2013) Kiev v opornom karkase glavnyh liniy i uzlov urbanizatsii Evropy: Scenarii budushchego. In: Rudenko, L. (ed.) Changes of urban space in Ukraine, pp. 60-72. Kyiv, Referat.

Nudelman, V. (2015) Kiev v Evropeyskom izmerenii. In: Rudenko, L. (ed.) Cities functions and its impact to the space, pp. 119-134. Kyiv, Phenix.

Peck, J. \& Tickell, A. (2002) Neoliberalizing space. Antipode, 34 (3), pp. 380-404. DOI: 10.1002/9781444397499.ch2

Peck, J., Theodore, N. \& Brenner, N. (2013) Neoliberal urbanism redux? International Journal of Urban and Regional Research, 37(3), pp. 10911099. DOI: $10.1111 / 1468-2427.12066$ 
Peck, J., Brenner, N. \& Theodore, N. (2017) Actually existing neoliberalism. In: Cahill, D., et al. (eds.) Sage handbook of neoliberalism, pp. 3-16. Washington, DC, Sage Publications.

Pickles, J. \& Smith, A. (eds.) (1998) Theorising transition: The political economy of post-communist transformation. London, Routledge.

Pidgrushnyi, G. (2015) Postindustrialnye transformatsii economiki bolshih gorodov Ukrainy. In: Rudenko, L. (ed.) Cities functions and its impact to the space, pp. 102-118. Kyiv, Phenix.

Salvati, L. \& Zitti, M. (2017) Sprawl and mega-events: Economic growth and recent urban expansion in a city losing its competitive edge (Athens, Greece). Urbani izziv, 28(2), pp. 110-121.

DOI: 10.5379/urbani-izziv-en-2017-28-02-003

Sassen, S. (2016) The global city: Strategic site, new frontier. In: Keiner, M., Koll-Schretzenmayr, M. \& Schmid, W. A. (eds.) Managing urban futures: Sustainability and urban growth in developing countries, pp. 89104. London, Routledge.

Short, J. R. (2004) Global metropolitan: Globalizing cities in a capitalist world. London, Routledge.

Sluka, N. (ed.) (2007) Globalnyi gorod: teoria I realnost. Moscow, Avanglion.

Sluka, N. (2009) Geodemographicheskie phenomeny globalnyh gorodov. Smolensk, Oykumena.

Soja, E. W. (1996) Thirdspace. Journeys to Los Angeles and other real-and-imagined places. Malden, MA, Blackwell.

Soja, E. W. (2009) Vom "Zeitgeist" zum "Raumgeist." New twist on the spatial turn. In: Döring, J. \& Thielmann, T. (ed.) Spatial Turn. Das Raumparadigma in den Kultur- und Sozialwissenschaften. pp. 241-262. Bielefeld, Transcript.

Sosnova, N. (2011) Transformatsia miskogo seredovyshcha yak vidobrazhennja economichnyh I suspilnyh processiv u naibilshyh mistah Ukrainy. In: Palekha, M. (ed.) Experience and perspectives of development of cities in Ukraine and other countries. Development problems of biggest cities in Ukraine: Scientific Works Collection, pp. 98-106. Kyiv, Dipromisto.

Stenning, A., Smith, A., Rochovska, A. \& Swiatek, D. (2010) Domesticating neo-liberalism: Spaces of economic practice and social reproduction in post-socialist cities. Oxford, Wiley-Blackwell. DOI: $10.1002 / 9781444325409$

Stevens, Q. (2006) The shape of urban experience: A reevaluation of Lynch's five elements. Environment and Planning B: Planning and Design, 33(6), pp. 803-823. DOI: 10.1068/b32043

Swyngedouw, E., Moulaert, F. \& Rodriguez, A. (2002) Neoliberal urbanization in Europe: Large-scale urban development projects and the new urban policy. Antipode, 34 (3), pp. 380-404. DOI: $10.1002 / 9781444397499 . c h 9$

Sýkora, L. (2009) Post-socialist cities. In: Kitchin, R. \& Thrift, N. (eds.) International Encyclopedia of Human Geography, 8, pp. 387-395. DOI: 10.1016/B978-008044910-4.01072-5

Sýkora, L. \& Bouzarovski, S. (2012) Multiple transformations: Conceptualising the post-communist urban transition. Urban Studies, 49(1), pp. 43-60. DOI: 10.1177/0042098010397402

Taylor, P. J. (2006) Cities within spaces of flows: Theses for a materialist understanding of the external relations of cities. In: Taylor, P. J., Derudder, B., Saey, P. \& Witlox, F. (eds.) Cities in Globalization, pp. 287-297. London, Routledge. DOI: 10.4324/9780203962978

Taylor, P., Derudder, B., Saey, P. \& Witlox, F. (eds.) (2007) Cities in globalization: Practices, policies and theories. London, Routledge.
Taylor, P., Ni, P., Derudder, B., Hoyler, M., Huang, J. \& Witlox, F. (eds.) (2010) Global urban analysis: A survey of cities in globalization. London, Earthscan.

Trubina, E. (2011) Gorod v teorii: opyt osmyslenia prostranstva. Moscow, Novoe literaturnoe obozrenie. 